\title{
Routes for Potassium Ions across Mitochondrial Membranes: A Biophysical Point of View with Special Focus on the ATP-Sensitive $\mathrm{K}^{+}$Channel
}

\author{
Yevheniia Kravenska (D), Vanessa Checchetto and Ildiko Szabo * \\ Department of Biology, University of Padova, 35131 Padova, Italy; k.evgeniya.v@gmail.com (Y.K.); \\ vanessa.checchetto@unipd.it (V.C.) \\ * Correspondence: ildiko.szabo@unipd.it
}

check for

updates

Citation: Kravenska, Y.; Checchetto, V.; Szabo, I. Routes for Potassium Ions across Mitochondrial Membranes: A Biophysical Point of View with Special Focus on the ATP-Sensitive $\mathrm{K}^{+}$ Channel. Biomolecules 2021, 11, 1172. https: / / doi.org/10.3390/

biom 11081172

Academic Editor: Ferdinando Palmieri

Received: 22 June 2021

Accepted: 2 August 2021

Published: 8 August 2021

Publisher's Note: MDPI stays neutral with regard to jurisdictional claims in published maps and institutional affiliations.

Copyright: (c) 2021 by the authors. Licensee MDPI, Basel, Switzerland. This article is an open access article distributed under the terms and conditions of the Creative Commons Attribution (CC BY) license (https:// creativecommons.org/licenses/by/ $4.0 /)$.

\begin{abstract}
Potassium ions can cross both the outer and inner mitochondrial membranes by means of multiple routes. A few potassium-permeable ion channels exist in the outer membrane, while in the inner membrane, a multitude of different potassium-selective and potassium-permeable channels mediate $\mathrm{K}^{+}$uptake into energized mitochondria. In contrast, potassium is exported from the matrix thanks to an $\mathrm{H}^{+} / \mathrm{K}^{+}$exchanger whose molecular identity is still debated. Among the $\mathrm{K}^{+}$channels of the inner mitochondrial membrane, the most widely studied is the ATP-dependent potassium channel, whose pharmacological activation protects cells against ischemic damage and neuronal injury. In this review, we briefly summarize and compare the different hypotheses regarding the molecular identity of this patho-physiologically relevant channel, taking into account the electrophysiological characteristics of the proposed components. In addition, we discuss the characteristics of the other channels sharing localization to both the plasma membrane and mitochondria.
\end{abstract}

Keywords: mitochondria; ion channels; electrophysiology; ATP-dependent potassium channel

\section{Introduction}

In 1961, Peter Mitchell formulated the chemiosmotic theory [1], according to which (i) electron transport through the respiratory chain of mitochondria promotes the flow of protons from the matrix into the intermembrane space, allowing the formation of a $\mathrm{H}+$ gradient (protonmotive force), (ii) this process is directly related to the activity of $\mathrm{F}_{1} \mathrm{~F}_{\mathrm{O}}$-ATPsynthase and to the production/hydrolysis of ATP, (iii) the inner mitochondrial membrane (IMM) is impermeable to ions, including $\mathrm{H}^{+}$. Despite this assumption, the author predicted the necessity for ions to be transported through the IMM. Indeed, extensive research over the last few decades has highlighted an important role for potassium transporters / channels in the regulation of the IMM potential $(\Delta \psi)$, redox state and mitochondrial volume, as summarized by recent, detailed reviews, e.g., [2-7]. By modulating these important factors, $\mathrm{K}^{+}$channels impact not only on bioenergetic efficiency and ATP production by mitochondria, but also on cellular signaling events such as, for example, apoptotic signaling [8,9], Wnt signaling [10], and cGMP-related pathways [11]. As a consequence, IMM $\mathrm{K}^{+}$channels emerged as important players in the context of cancer [12], cardioprotection [13], and neuronal protection [9], and may even play a role in the inflammatory response [14]. Thanks to intensive research carried out by several excellent groups in the field, mitochondrial potassium channels are currently in the spotlight of the scientific community working on different pathologies.

\section{Multiple Routes for Potassium across the Outer and Inner Mitochondrial Membranes}

The passage of this ion, which is normally present at a concentration greater than $100 \mathrm{mM}$ in the cytosol, follows the electrochemical gradient largely dictated by the very negative resting membrane potential across the IMM (around $-180 \mathrm{mV}$ ). Mitochondria 
maintain the matrix $\mathrm{K}^{+}$concentration at $150-180 \mathrm{mM}$ [15]. The influx of $\mathrm{K}^{+}$can occur through the mitochondrial channels, while the excess $\mathrm{K}^{+}$matrix is expelled by the antiporter $\mathrm{K}^{+} / \mathrm{H}^{+}$. The consensus view is that the voltage-dependent anion channel isoforms (VDACs) of the outer mitochondrial membrane (OMM) $[16,17]$ are sufficiently large to allow the flux of different metabolites and ions, including $\mathrm{K}^{+}$. Indeed, VDACs (VDAC13) show a slight cation selectivity in the partially closed state [18] and, although tightly regulated [19], they may ensure a continuous flux of potassium into and out of the mitochondrial intermembrane space, allowing an equilibrium between this compartment and the cytosol. It was surprising, therefore, that an inwardly rectifying $\mathrm{K}^{+}$channel that was responsive to voltage, osmotic pressure and cAMP has been identified directly by patch clamping mitochondria isolated from the spinal cord [20]. The physiological importance of this channel is not clear, but importantly, this work confirmed the idea that VDAC may adopt a completely closed state across the OMM [21], since no VDAC-like current was observed by electrophysiology. It is of note that even though VDACs were shown to mediate calcium flux across the OMM [22,23], a small channel, namely a functional $\alpha 7$ nicotinic acetylcholine receptor, was able to regulate calcium flux across the OMM [24], suggesting that the OMM might indeed be not freely permeable to ions such as calcium and potassium.

In contrast to the OMM, the IMM harbors a number of potassium channels, and a $\mathrm{K}^{+} / \mathrm{H}^{+}$exchanger. Given that several recent reviews dealt with the former topic (see also [5] in this Special Issue), here we only mention the main classes of $\mathrm{K}^{+}$channels, that can allow the passage of only $\mathrm{K}^{+}\left(\mathrm{K}^{+}\right.$-selective channels) or of other cations as well $\left(\mathrm{K}^{+}\right.$permeable channels). In the former category, the following channels have been identified directly by patch clamping of mitochondria: (1) ATP-dependent potassium channel [25]; (2) voltage-gated shaker type $\mathrm{K}^{+}$channel Kv1.3 [26,27]; (3) calcium-activated intermediateconductance $\mathrm{K}^{+}$channel (IK(Ca)) [28]; (4) calcium-activated big conductance potassium channel (BK(Ca)) [29,30]; (5) small-conductance calcium-activated $\mathrm{K}^{+}$channel (SK(Ca)) [31]; (6) renal medullary channel ROMK [32]; and (7) two-pore potassium channel TASK-3 [33]. The hyperpolarization-activated, cyclic- nucleotide-gated channel isoforms HCNs belong to the latter category of potassium-permeable channels [34,35].

In most of the above studies, the mitochondrial channels recorded in the IMM highly resembled those of the plasma membrane (PM), at least regarding their conductance, which is a basic biophysical feature of all ion channels. In fact, our current understanding is that, for example in the cases of TASK-3, IK(Ca), SK(Ca), Kv1.3, and HCN, the same proteins residing in the PM locate to the IMM as well, giving rise to comparable channel activities. Although mitoplasts are well distinguishable from other organelles when performing patch-clamp experiments, more sophisticated methodologies that exclude the possibility of contamination are also available [36,37]. In most studies, multiple techniques were exploited to confirm dual localization of a given protein, such as Western blot to assess contaminations by other membranes, immunogold electron microscopy and modulation of mitochondrial activity and/or $\mathrm{K}^{+}$uptake into mitochondria by pharmacological or genetic tools. Kv7.4 [38] and Kv1.5 [39] have been identified in the IMM of cardiomyocytes and macrophages, respectively, using biochemical/pharmacological tools only.

The mechanism of dual targeting is not known for most IMM K${ }^{+}$channels. With the exception of HCNs and ROMK2 (see below), bioinformatic tools do not predict mitochondrial localization due to the lack of a typical N-terminal mitochondria-targeting sequence. Our recent data indicate that, for example, in the case of Kv1.3, association of the channel with caveolin-1 promotes PM targeting, while the lack of such functional coupling causes accumulation of the channel in mitochondria, with severe consequences on mitochondrial function and cell survival [40]. Whether association with caveolin may play a role in channel trafficking and subcellular targeting also in the case of other $\mathrm{K}^{+}$ channels is an interesting point for future investigation. Another interesting candidate worth consideration is SKD3 (suppressor of potassium transport defect 3), also known as caseinolytic peptidase B protein homolog (CLPB), a broadly expressed member of the 
family of ATPases associated with diverse cellular activities (AAA+). A recent study highlighted that ATP controls the ability of SKD3 to self- associate or form complexes with other proteins in the intermembrane space of mitochondria [41]. Human CLPB contains an ankyrin-repeat domain, and, for example, channels of the Kv7 family harbor an ankyrinbinding domain [42]. Whether and how this IMS-located protein might regulate IMM K ${ }^{+}$ channel import/assembly/function or exert a quality control remains an open question.

Since patch clamping of mitoplasts (i.e., of mitochondria devoid of the OMM) is technically demanding, unfortunately a complete biophysical and pharmacological characterization has not been carried out in all cases, thus hampering a strict comparison of the PM-located channels with those of their IMM counterparts. Nevertheless, as illustrated in Table 1, a relatively good match has been found in many cases, at least regarding the conductance values. It is of note that for some of the mentioned channels, the range of described conductance values is quite wide, which can be due to several factors. First of all, the composition of the working solutions (in particular, by the concentration of $\mathrm{Ca}^{2+}$ and $\mathrm{K}^{+}$) and the type of cells/tissues/organisms are not the same in each work. Depending on the cell type, the general composition and characteristics of the channels may differ, for example, due to lack of interaction with specific receptors/regulatory subunits. Within the same family of channels, differences in conductance can be explained by alternative splicing, post-translational modifications, as well as by the homo- and heteromerization of the channel [6]. The protocol applied to elicit channel activity is also important, since a wider range of voltages makes it possible to determine the conductance with greater accuracy.

Important questions are still unanswered, in particular regarding $\mathrm{Kv}$ channels that are normally active in the PM at depolarizing voltages. Thus, the factors allowing these channels to operate at the very negative IMM potential $(\Delta \psi$, around -160 to $-180 \mathrm{mV})$ remain to be determined. Although the fact that, e.g., Kv1.3 is active in the IMM is indicated by changes in $\Delta \psi$ upon its inhibition using specific blockers [26], recent studies pointed to its involvement in the apoptotic cascade via its interaction with complex I [43] and to its role in linking respiration to proliferation, not necessarily relying on Kv1.3 ability to mediate $\mathrm{K}^{+}$flux [44]. It is interesting to note that other mitochondrial potassium channels are also physically and/or functionally coupled to respiratory chain complexes: mitoBK (Ca) functionally and physically interacts with complex IV [45], mitoKATP function has been linked to complex II [46,47], ROMK2 is associated with complex V [48], while TASK3 [49] and HCN [34] also seem to interact with complex V. It is tempting to speculate that the specific association of different $\mathrm{K}^{+}$channels with distinct OXPHOS complexes may allow a reciprocal fine-tuning of their activities.

Table 1. Comparison of single-channel conductance values of the plasma membrane- and the inner mitochondrial membranelocated $\mathrm{K}^{+}$channels obtained by the patch-clamp technique (in excised inside-out or mitoplast-attached configurations). Open probabilities are also reported, where available.

\begin{tabular}{|c|c|c|}
\hline Channel & Conductance of PM Channel & Conductance of Mitochondrial Channel \\
\hline \multirow{2}{*}{$\begin{array}{l}\text { ATP- } \\
\text { dependent } \mathrm{K}^{+} \\
\text {channel }\end{array}$} & $\begin{array}{l}13-68 \mathrm{pS} \text { in } 140 \mathrm{mM} \mathrm{KCl}[50,51] \\
20-80 \mathrm{pS} \text { in } 140 \text { (bath)/5.4-100 (pipette) } \mathrm{mM} \mathrm{KCl} \mathrm{[52]} \\
\sim 80 \mathrm{pS} \text { in } 145 \mathrm{mM} \mathrm{K}^{+}[53,54] \\
135 \mathrm{pS} \text { in } 120 \text { (bath)/60 (pipette) } \mathrm{mM} \mathrm{K}^{+}[55]\end{array}$ & From 10 to $100 \mathrm{pS}$ in $150 \mathrm{mM} \mathrm{KCl}$ (see Table 2). \\
\hline & $\begin{array}{l}\text { Open probability: } \\
\text { NPo } \sim 0.32 \text { at }-100 \mathrm{mV}[51] \\
\approx 0.9 \text { between }-100 \text { and } 60 \mathrm{mV}[54]\end{array}$ & $\begin{array}{l}\text { Open probability: } \\
0.74 \text { at } 40 \mathrm{mV} \text { [56] } 0.57 \text { at }-50 \mathrm{mV} \text { [32] } 0.24 \text { at } \\
-60 \mathrm{mV} \text { [57] }\end{array}$ \\
\hline
\end{tabular}


Table 1. Cont

\begin{tabular}{|c|c|c|}
\hline Channel & Conductance of PM Channel & Conductance of Mitochondrial Channel \\
\hline \multirow{2}{*}{$K v 1.3$} & $24 \mathrm{pS}$ in $140 \mathrm{mM} \mathrm{KCl} \mathrm{[58]}$ & $\begin{array}{l}\sim 25 \mathrm{pS} \text { in } 134 \mathrm{mM} \mathrm{K}^{+} \text {[26] } \\
109 \mathrm{pS} \text { in } 150 \mathrm{mM} \mathrm{KCl} \mathrm{[27]}\end{array}$ \\
\hline & $\begin{array}{l}\text { Open probability: } \\
\sim 0.013 \text { at } 50 \mathrm{mV} \text { [58] }\end{array}$ & $\begin{array}{l}\text { Open probability: } \\
0.5 \text { at }-60 \mathrm{mV} \text { to } 0.75 \text { at } 60 \mathrm{mV} \text { [27] }\end{array}$ \\
\hline \multirow[b]{2}{*}{$B K(C a)$} & $\begin{array}{l}\sim 180 \mathrm{pS} \text { in } 143 \mathrm{KCl}[59] \\
187 \mathrm{pS} \text { in } 144 \mathrm{KCl}[60] \\
260-293 \mathrm{pS} \text { in } 150 \mathrm{KCl}[61] \\
250 \text { to } 300 \mathrm{pS} \text { in } 150 \mathrm{mM} \mathrm{K}^{+} \text {(e.g., [62]) }\end{array}$ & $\begin{array}{l}190 \mathrm{pS} \text { in } 130 \text { (bath) } / 10 \text { (pipette) } \mathrm{mM} \mathrm{K}^{+}[63] \\
145 \text { to } 307 \mathrm{pS} \text { in } 150 \mathrm{mM} \mathrm{K}^{+}[11,29,64-68]\end{array}$ \\
\hline & $\begin{array}{l}\text { Open probability: } \\
\sim 0.27 \text { at }-40 \mathrm{mV}[61]\end{array}$ & $\begin{array}{l}\text { Open probability: } \\
0.79 \text { at } 80 \mathrm{mV}[63] 0.5 \text { at }-33 \mathrm{mV}[29] \\
\sim 0.16 \text { at }-60 \mathrm{mV} \text { to } \sim 0.94 \text { at } 60 \mathrm{mV}[65] \\
\sim 0.54-0.9 \text { at } 60 \mathrm{mV}[11,66] \\
\sim 0.25-0.76 \text { at }-40 \mathrm{mV}[67,68]\end{array}$ \\
\hline \multirow{2}{*}{$I K(C a)$} & $\begin{array}{l}\sim 25 \mathrm{pS} \text { in } 150 \text { (bath)/140 (pipette) } \mathrm{mM} \mathrm{KCl} \mathrm{[69]} 31 \mathrm{pS} \text { in } \\
160 \mathrm{mM} \mathrm{K}^{+}[70] \\
33-34 \mathrm{pS} \text { in } 130 \text { (bath)/145 (pipette) } \mathrm{mM} \mathrm{KCl} \mathrm{[71]} \\
39 \mathrm{pS} \text { in } 120 \mathrm{mM} \mathrm{K}^{+}[72]\end{array}$ & \multirow{2}{*}{10 to $90 \mathrm{pS}$ in $150 \mathrm{mM} \mathrm{KCl} \mathrm{[28]}$} \\
\hline & $\begin{array}{l}\text { Open probability: } \\
0.6 \text { and } 0.4 \text { at }-50 \text { and } 50 \mathrm{mV} \text {, respectively [69] } \\
<0.5 \text { between }-120 \text { and } 60 \mathrm{mV} \text { [70] } \\
0.021 \text { at }-60 \mathrm{mV}, 0.013 \text { at }-20 \mathrm{mV} \text { [71] }\end{array}$ & \\
\hline$S K(C a)$ & $\begin{array}{l}8 \mathrm{pS} \text { in } 200 \text { (bath) /4 (pipette) } \mathrm{mM} \mathrm{KCl} \mathrm{[73]} \\
15 \mathrm{pS} \text { in } 140 \mathrm{mM} \mathrm{KCl} \mathrm{[74]} \\
40-50 \mathrm{pS} \text { in } 140 \mathrm{mM} \mathrm{KCl} \text { (pipette) [75] }\end{array}$ & $\begin{array}{l}\text { Not determined at single channel level (for } \\
\text { whole-mitoplast recording, see [31]) }\end{array}$ \\
\hline \multirow[b]{2}{*}{ ROMK } & $\begin{array}{l}\sim 30 \mathrm{pS} \text { in } 5 \text { (bath)/140 (pipette) } \mathrm{mM} \mathrm{KCl} \mathrm{[76]} \\
39 \mathrm{pS} \text { in } 145 \mathrm{~K}^{+} \mathrm{mM} \text { [77] }\end{array}$ & $94 \mathrm{pS}$ in $150 \mathrm{mM} \mathrm{KCl}$ [32] \\
\hline & $\begin{array}{l}\text { Open probability: } \\
0.88 \text { between }-40 \text { and }-80 \mathrm{mV}[76] \\
0.82 \text { at }-60 \mathrm{mV} \text { and } 0.92 \text { at }-30 \mathrm{mV} \text { [77] }\end{array}$ & $\begin{array}{l}\text { Open probability: } \\
0.21 \text { at } 50 \mathrm{mV} \text { to } 0.57 \text { at }-50 \mathrm{mV} \text { [32] }\end{array}$ \\
\hline TASK-3 & $\begin{array}{l}18 \mathrm{pS} \text { in } 140 \mathrm{mM} \mathrm{KCl} \text { (pipette) [78] } \\
17-27 \mathrm{pS} \text { in } 140 \mathrm{mM} \mathrm{KCl} \mathrm{[79]}\end{array}$ & $12-83 \mathrm{pS}$ in $150 \mathrm{mM} \mathrm{KCl}$ [33] \\
\hline $\mathrm{HCN}$ & $\begin{array}{l}\sim 1 \mathrm{pS} \text { for } \mathrm{I}_{\mathrm{f}} \text { in } 5.4 \text { (bath)/70 (pipette) } \mathrm{mM} \mathrm{KCl} \mathrm{[80]} \\
0.46 \text { and } 1.71 \mathrm{pS} \text { for } \mathrm{HCN} 1 \text { and } \mathrm{HCN} 2 \text {, respectively } \\
\text { (in } 110 \mathrm{mM} \mathrm{KCl} \text { [ [81] }\end{array}$ & $\begin{array}{l}\text { Not determined at single channel level (for } \\
\text { whole-mitoplast recording, see [34] }\end{array}$ \\
\hline
\end{tabular}

As mentioned above, all these channel activities mediate influx of $\mathrm{K}^{+}$into the matrix. This $\mathrm{K}^{+}$flux in the presence of permeable anions (e.g., inorganic phosphate) takes place along with osparison of single-channel conductance values ofmotically obligated water and therefore results in mitochondrial swelling. Therefore, to control $\mathrm{K}^{+}$concentration, $\mathrm{a}$ $\mathrm{K}^{+} / \mathrm{H}^{+}$exchanger ensures exit of $\mathrm{K}^{+}$in the so-called $\mathrm{K}^{+}$cycle [82]. The molecular identity of this exchanger remains debated, even though convincing evidence has been accumulated in favor of the hypothesis that envisions LETM1 as the $\mathrm{K}^{+} / \mathrm{H}^{+}$exchanger (for a recent review see [83]). LETM1 has originally been identified as a protein linked to mitochondrial $\mathrm{K}^{+}$homeostasis [84], but was later proposed to be the long-sought electroneutral calcium/proton antiporter $\left(2 \mathrm{H}^{+} / \mathrm{Ca}^{2+}\right)$ of the IMM $[85,86]$. However, a more recent work provided compelling evidence, using a novel potassium probe mitoPOP able to monitor the mitochondrial $\mathrm{K}^{+}$concentration, that (i) LETM1 deletion caused $\mathrm{K}^{+}$accumulation in the mitochondrial matrix; (ii) LETM1, able to transport both $\mathrm{K}^{+}$and $\mathrm{Na}^{+}$, regulated mitochondrial calcium fluxes in a sodium-dependent manner [87]. Thus, in the so-called calcium cycle, LETM1 would exert a regulatory effect on calcium exit through the $\mathrm{Na}^{+} / \mathrm{Ca}^{2+}$ antiporter, whose function would be linked to the extrusion of matrix Na+ via LETM1. Unfortunately, more recent works $[88,89]$ did not consider this possibility when interpreting experimental 
results. Independently of the nature of the transported ions, LETM1 remains an important player in mitochondrial biology, as it has recently been shown to cause cristae-like invaginations even in artificial liposomes, raising the possibility that this transporter contributes to cristae shaping [90]. A previous work linked LETM1 function to mitochondrial fragmentation, but observed no changes in mitochondrial morphology in fibroblasts from Wolf-Hirschhorn syndrome patients, in which monoallelic LETM1 deletion occurs [91].

\section{The Mitochondrial ATP-Dependent Potassium Channel(s)}

In addition to uncertainties regarding LETM1, the field of mitochondrial potassiumtransporting proteins has to deal with the molecular identification of one of the most important and most well-known activities, the elusive mitochondrial ATP-dependent potassium channel (KATP). KATP exerts crucial function in the PM, for example by regulating insulin secretion [92]. The PM channel comprises four channels forming subunits Kir6.1 or Kir6.2 (encoded by KCNJ8 and KCNJ11, respectively) and of four regulatory SUR subunits (SUR1, SUR2A/SUR2B, encoded by $A B C C 8$ and $A B C C 9$, respectively), which act as sulphonylurea receptors. The association of a particular SUR with a specific Kir6.x subunit constitutes the ATP-dependent $\mathrm{K}^{+}$current (KATP) in each tissue (for reviews, see e.g., $[92,93]$. Soon after the first report that applied the patch clamp technique to mitoplasts obtained by osmotic swelling and rupture of the OMM [94], Inoue and colleagues identified, using the same technique, a channel in the IMM that was inhibited by ATP, and was therefore named as mitoKATP [25].

The conductance of KATP of the PM ranges from 33-35 pS for the channels composed of Kir6.1 to 67-80 pS for those constituted by Kir6.2, in symmetrical $140 \mathrm{mM} \mathrm{KCl} \mathrm{(for}$ review see e.g., [18]). However, conductance as low as $13 \mathrm{pS}$ (in $140 \mathrm{mM}$ symmetrical $\mathrm{KCl}$ solution) was recorded in rat mesenteric artery vascular smooth muscle cells (VSMC) [51]. In this latter cell type, the diversity of molecular entities of KATP channels is illustrated by their single-channel conductance ranging from 13 to $135 \mathrm{pS}$, with distinct conductance values of 13, 20, 50, 111 and $135 \mathrm{pS}$, recorded under similar ionic conditions in various studies $[51,95]$.

Attribution of these channel activities with different conductance values to KATP in most experiments is based on the pharmacological profiling of channel activities. The hallmarks of PM KATP comprise inhibition by ATP $/ \mathrm{Mg}^{2+}$ or glibenclamide and activation by P-1075, BMS 191095, cromakalim, pinacidil and nicorandil [96-102]. Therefore, these drugs have been tested on mitochondrial $\mathrm{K}^{+}$channel activities by different groups. In addition, diazoxide was identified as an agent that activates mitoKATP more efficiently than PM KATP, and HMR 1098 was proposed as a specific inhibitor of PM KATP but not of mitoKATP $[103,104]$.

The above pharmacological drugs were then exploited in different cell types to measure mitoKATP activity in mitoplasts directly by patch clamp. As mentioned above, in the first study, a $\sim 10 \mathrm{pS}$ channel was identified as mitoKATP [25], but in subsequent studies, different conductance values were observed. Table 2 summarizes all data published to date, in which the main biophysical and pharmacological properties of mitoKATP activity in the native IMM were determined using the patch clamp technique. Although in two studies (in Jurkat [56] and in rat liver mitochondria [25]) an ATP-sensitive channel with low conductance was observed (15 and $9.7 \mathrm{pS}$ in $100 / 33 \mathrm{mM} \mathrm{KCl}$ or symmetrical $150 \mathrm{mM} \mathrm{KCl}$, respectively), in other works, the conductance reached $\sim 100 \mathrm{pS}$ (in $150 \mathrm{mM}$ $\mathrm{KCl})[32,57,105]$. Thus, the conductance values around $100 \mathrm{pS}$ recorded in native mitochondrial membranes are compatible with the ones observed for PM KATP formed by Kir6.2-SUR2A complexes [53,54]. This finding, along with the pharmacological profile mentioned above, prompted the researchers to propose the Kir6.2 inward rectifying channel as the main pore-forming constituent of mitoKATP. 


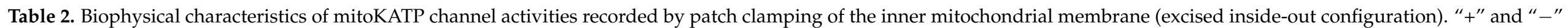
denote activation or inhibition of mitoKATP, respectively.

\begin{tabular}{|c|c|c|c|c|c|}
\hline \multirow{2}{*}{ Tissue/Cell Origin } & \multirow{2}{*}{$\begin{array}{l}\text { Method of Mitoplast } \\
\text { Preparation }\end{array}$} & \multirow{2}{*}{ Recording Medium } & \multirow{2}{*}{$\begin{array}{l}\text { Single-Channel } \\
\text { Conductance } \\
\end{array}$} & \multirow{2}{*}{ Modulation } & \multirow{2}{*}{ Reference } \\
\hline & & & & & \\
\hline Rat liver & $\begin{array}{l}\text { Giant mitoplasts obtained by } \\
\text { digitonin-swelling fusion }\end{array}$ & $\begin{array}{l}\text { - } \quad \text { Pipette: } 100 \mathrm{mM} \mathrm{KCI}, 7.5 \mathrm{mM} \text { sodium-MOPS, } \\
\text { pH 7.2, } 1 \mathrm{mM} \text { EGTA, } 0.55 \mathrm{mM} \mathrm{CaCl}_{2} \\
\text { - } \quad \text { Bath: } 33.3 \mathrm{mM} \text { KCI. 66.7 mM NaCI, } 7.7 \mathrm{mM} \\
\text { Na-MOPS, pH 7.2, } 2 \mathrm{mM} \mathrm{EGTA}\end{array}$ & $\begin{array}{l}9.7 \mathrm{pS} \text { at negative membrane } \\
\text { potentials }\end{array}$ & $\begin{array}{ll}- & \text { ATP } 2 \mathrm{mM}(-) \\
- & 4 \text {-aminopyridine }-5 \mathrm{mM}(-) \\
\text { - } & \text { glybenclamide } 5 \mu \mathrm{M}(-)\end{array}$ & {$[25]$} \\
\hline Jurkat lymphocyte & Swelling & $\begin{array}{l}\text { Pipette/bath: } 150 \mathrm{mM} \mathrm{KCl}, 10 \mathrm{mM} \text { HEPES and } 100 \\
\text { (or 200) } \mu \mathrm{M} \mathrm{CaCl} 2(\mathrm{pH}=7.2)\end{array}$ & $\begin{array}{l}15 \text { and } 82 \mathrm{pS} \text { at negative and } \\
\text { positive potentials, respectively }\end{array}$ & $\begin{array}{ll}\text { - } & \text { 5-hydroxydecanoic acid } 1 \mathrm{mM} \\
& (-) \\
\text { - } & \text { nitric oxide } 2 \mu \mathrm{M}(-) \\
\text { - } & \text { ATP } 0.5-25 \mathrm{mM}(-)\end{array}$ & {$[56]$} \\
\hline Human dermal fibroblast & Swelling & $\begin{array}{l}\text { Pipette/bath: } 150 \mathrm{KCl}, 10 \mathrm{mM} \\
\mathrm{HEPES} \text {, and } 200 \\
\mathrm{CaCl}_{2} \text { at } \mathrm{pH} 7.2 \text {. }\end{array}$ & $100 \mathrm{pS}$ & $\begin{array}{ll}- & 1 \mathrm{mM} \mathrm{Mg}^{2+} \text { plus } 500 \mu \mathrm{M} \text { ATP } \\
& (-) \\
\text { - } & \text { diazoxide } 30 \mu \mathrm{M}(+) \\
\text { - } & \text { BMS } 191,09510 \mu \mathrm{M}(+) \\
\text { - } & \text { glibenclamide } 30 \mu \mathrm{M}(-) \\
& \text { 5-hydroxydecanoic acid } 150 \mathrm{mM} \\
& (-)\end{array}$ & [105] \\
\hline
\end{tabular}


Table 2. Cont.

\begin{tabular}{|c|c|c|c|c|c|}
\hline \multirow{2}{*}{ Tissue/Cell Origin } & \multirow{2}{*}{$\begin{array}{l}\text { Method of Mitoplast } \\
\text { Preparation }\end{array}$} & \multirow{2}{*}{ Recording Medium } & Single-Channel & \multirow{2}{*}{ Modulation } & \multirow{2}{*}{ Reference } \\
\hline & & & Conductance & & \\
\hline Overexpressing cells & & & & $\begin{array}{ll}- & 1 \mathrm{mM} \mathrm{Mg}^{2+} \text { plus } 500 \mu \mathrm{M} \text { ATP } \\
& (-) \\
\text { - } & \text { diazoxide }(+) \\
\text { glibenclamide } & 50 \mu \mathrm{M}(-, \text { partial } \\
\text { inhibition })\end{array}$ & \\
\hline $\begin{array}{l}\text { Primary } \\
\text { Human dermal } \\
\text { fibroblasts }\end{array}$ & Swelling & $\begin{array}{l}\text { Pipette/bath: } \\
150 \mathrm{mM} \text { of } \mathrm{KCl}, 10 \mathrm{mM} \\
\text { of } \mathrm{HEPES} \text {, and } 200 \mu \mathrm{M} \\
\text { of } \mathrm{CaCl}_{2} \text { at } \mathrm{pH}=7.2\end{array}$ & $100 \mathrm{pS}$ & $\begin{array}{ll}- & \text { naringenin }(\mathrm{Nar}) 10 \mu \mathrm{M}(+) \\
& \text { diazoxide } 30 \mu \mathrm{M}(+) \\
- & \text { 5-hydroxydecanoic acid } 500 \mu \mathrm{M} \\
& \text { (plus Nar) }(-) \\
\text { glibenclamide } 10 \mu \mathrm{M} \text { (plus } \\
\quad \text { Nar) }(-)\end{array}$ & [57] \\
\hline
\end{tabular}


Despite the fact that the molecular composition of mitoKATP was not elucidated, the field of mitoKATP channel underwent a rapid evolution when pharmacological studies highlighted an important role of this channel in cardioprotection, in particular in attenuating the damage caused by ischemia- reperfusion (for recent reviews see, e.g., [6,7,13]. Moreover, mitoKATP activation has been proposed to exert neuroprotective effects [106] and to modulate mitochondrial dynamics, biogenesis and neurodegenerative disorders such as Parkinson [107]. Interestingly, diazoxide, the activator of mitoKATP, was shown to improve memory in a mouse model of Alzheimer's disease and ameliorate amyloid- $\beta$ and tau pathologies [108]. Neuronal injury was also attenuated in models of the metabolic disease methyl-malonic acidemia by mitoKATP openers [109].

Most of the above studies underlining the patho-physiological role of mitoKATP were carried out with diazoxide as a channel activator. However, this drug also exerts $\mathrm{K}^{+}$channel-independent effects, such as inhibition of complex II of the respiratory chain (succinate dehydrogenase) and uncoupling action, leading researchers to question the role of mitoKATP in ischemic preconditioning [110]. Moreover, diazoxide seems to also have an impact on the expression of some proteins, as it upregulates the two components of the calcium-release-activated calcium channel ( $\mathrm{I}_{\mathrm{CRAC}}$, also called the SOCE channel), STIM1 and Orai1 in cardiomyocytes [111]. The antioxidant $N$-acetyl cysteine (NAC), 5hydroxydecanoate (5-HD), and the MAPK pathway inhibitor UO126 were able to attenuate diazoxide-induced upregulation of STIM1 and Orai1 expression, suggesting that an ROSand MAPK-dependent pathway is activated by this mitoKATP opener. The authors hypothesized that alteration of the distribution pattern of STIM1, causing decreased $\mathrm{Ca}^{2+}$ influx into the cells, may contribute to cardioprotection against ischemic insults. However, direct electrophysiological evidence that $\mathrm{I}_{\mathrm{CRAC}}$ activity is decreased in cells incubated with diazoxide has not been reported.

Thus, while the protective effect of diazoxide against ischemic damage has been confirmed in several studies, the specificity of action via mitoKATP channels could not be proven in the absence of the molecular identity of this channel. As mentioned above, based on the conductance values observed in native IMM and by analogy with the PM KATP channel, Kir6.2 was first proposed as the pore-forming component, while SUR subunits were proposed as regulatory components of this complex (Figure 1). However, mito KATP channel activity, determined using the thallium $\left(\mathrm{Tl}^{+}\right)$flux assay in mitochondria isolated from WT or Kir6.2-/- littermate hearts was identical, even though the channel was required for the action of diazoxide to promote ischemic preconditioning. The authors therefore concluded that Kir6.2 is not a component of mitoKATP [112]. Direct electrophysiological recordings on mitoplasts from Kir6. $2^{-/-}$animals would be useful to further strengthen such a conclusion.

As an alternative to the Kir6.2 hypothesis, a multi-protein complex comprising complex II (succinate dehydrogenase), complex V (ATP synthase), an ATP-binding cassette protein 1 (mABC1), the phosphate carrier and the adenine nucleotide translocator (ANT) [46] was put forward. This multi-protein complex was incorporated into proteoliposomes and was characterized using the planar lipid bilayer electrophysiological technique, revealing a passage of $\mathrm{K}^{+}$, giving rise to a conductance of $200 \mathrm{pS}$ in $500 \mathrm{mM} \mathrm{K}$ (Hepes was used as a counterion). Interestingly, the observed activity showed low selectivity towards potassium but was inhibited by ATP, glybenclamide, or 5-HD, even in the presence of the activator diazoxide, as one would expect for mitoKATP. Unfortunately, mass spectrometry analysis was not provided on the complex isolated from the IMM, thus it cannot be excluded that other protein(s) present in the preparation are responsible for the observed channel activity. It is of note that ANT and the phosphate carrier can form ion channels on their own (for detailed review see e.g., [18]) and ANT was shown to also mediate proton leak [113]. In addition, highly purified complex $\mathrm{V}$ also forms channels under certain conditions (in a $\mathrm{Ca}^{2+}$-dependent way) with characteristics resembling the permeability transition pore (PTP) [114]. However, the described conductance values of ANT, complex V and the 
phosphate carrier measured in $\mathrm{K}^{+}$-based medium are different from those observed in the study of Ardehali and colleagues.

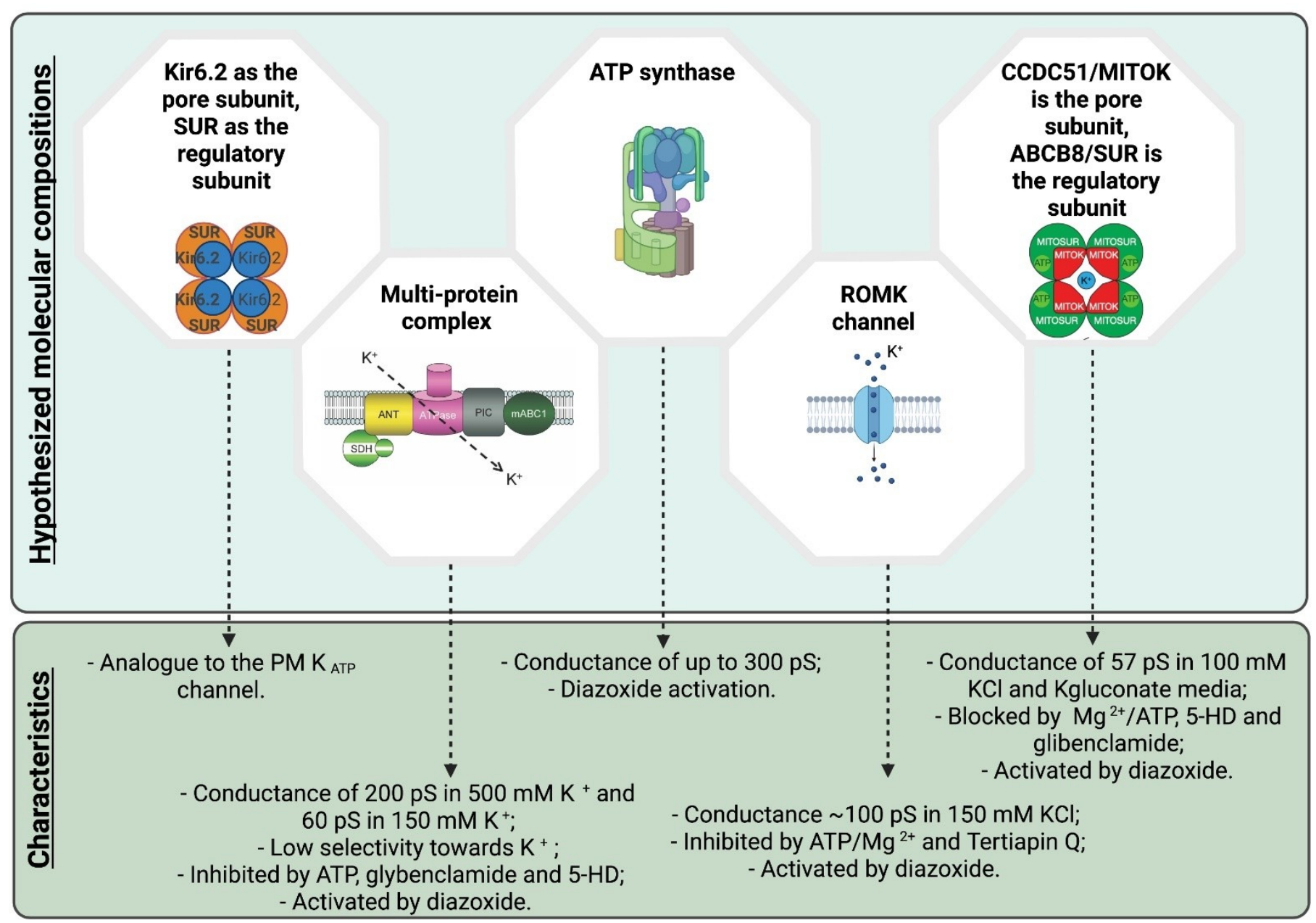

Figure 1. Schematic summary of the various hypotheses for the molecular composition of mitoKATP (see text for details). Created with BioRender.com (accessed on 22 June 2021).

Interestingly, a recent study re-proposed the participation of complex $\mathrm{V}$ in mitoKATP formation [115]. In particular, isolated ATP synthase (purity was, however, not assessed using mass spectrometry) was studied under ionic conditions that are physiologically relevant (with a ratio of $10^{6}: 1$ between $\mathrm{K}^{+}$and $\mathrm{H}^{+}$), and so in the presence of both protons and potassium ions. Based on electrophysiological experiments, the authors concluded that the ATP synthase allows the passage of $\mathrm{K}^{+}$in addition to protons (a unitary conductance of up to $\sim 300 \mathrm{pS}$ was observed) and underlies the so-called $\mathrm{K}^{+}$uniporter (mitoKATP). Interestingly, diazoxide in this context would act as an activator of mitoKATP by directly binding to the inhibitory protein of complex V, IF1 [116]. The proposal that complex V is responsible also for the formation of the PTP makes it all quite intriguing. Altogether, the authors proposed that the increase in ATP synthesis guided by $\mathrm{K}^{+}$and $\mathrm{H}^{+}$would allow complex $\mathrm{V}$ to operate as a primary mitochondrial uniporter of $\mathrm{K}^{+}$that regulates the match between energy supply and demand, and as the recruitable mitochondrial KATP channel that can limit ischemia-reperfusion injury. While genetic deletion or point mutants of certain subunits of the ATP synthase were shown to alter PTP properties in classical biochemical and electrophysiological assays [117-120], efforts to specifically study (diazoxide-dependent) $\mathrm{K}^{+}$transport across genetically modified ATP synthase complexes have not been taken into consideration up to date. 
In parallel with the above studies, research also focused on the renal outer medullary kidney channel (ROMK2) as a possible mitoKATP channel forming protein. ROMK2 is a short, mitochondria-targeted isoform of ROMK (also called Kir1.1, encoded by KCNJ1) which was shown to co-localize with mitochondrial ATP synthase in cardiomyocytes [48]. ROMK itself is ATP-sensitive and can associate with SUR2B. The single-channel conductance of PM ROMK at negative voltages is $32-43 \mathrm{pS}$ (with $110 \mathrm{mM} \mathrm{KCl}$ in the pipette). In the work of Foster and colleagues [48], short hairpin RNA-mediated knockdown of ROMK inhibited the ATPsensitive, diazoxide-activated component of mitochondrial thallium uptake, used as a proxy for potassium uptake into the matrix. Importantly, tertiapin $Q$, a venom toxin-derived inhibitor of ROMK channels, almost completely abolished thallium uptake. Moreover, the expression level of ROMK2 in the heart-derived cell line $\mathrm{H} 9 \mathrm{C} 2$ correlated well with sensitivity to cell death triggered by oxidative stress (via application of tertbutyl hydroperoxide (tBHP)). Thus, these results strongly suggest that ROMK2 might correspond, at least in some tissues, to mitoKATP. Electrophysiological evidence in favor of this hypothesis was provided more recently by the group of Adam Szewczyk, where patch clamp on dermal fibroblast mitochondria revealed a $100 \mathrm{pS}$ (in symmetric $150 \mathrm{mM} \mathrm{KCl}$ ) channel activity that was ascribed to ROMK and was activated by diazoxide while suppressed by ATP $/ \mathrm{Mg}^{2+}$, glibenclamide and 5-hydroxydecanoic acid [105]. Moreover, genetic overexpression of ROMK2 in heart-derived H9c2 cells enhanced mitoKATP activity directly recorded in the IMM by patch clamp. This channel displayed the typical biophysical and pharmacological characteristics of mitoKATP ( 100 pS in $150 \mathrm{mM} \mathrm{KCl}$, inhibition by ATP $/ \mathrm{Mg}^{2+}$, activation by diazoxide) and was inhibited by Tertiapin Q [32]. On the other hand, the observation that recombinant ROMK2 incorporated into nanodiscs shows a chord conductance of only $10 \mathrm{pS}$ in $50 / 150 \mathrm{mM} \mathrm{KCl}$, is intriguing [121]. Further work is required to find the reason for this difference in the biophysical properties of the recombinant versus native ROMK2 channels. While the electrophysiological and pharmacological properties of ROMK2 altogether are compatible with this protein being mitoKATP, a recent study using genetic, global or cardiomyocyte-specific knockout mice for ROMK2 discovered that isolated mitochondria from the latter mice still showed swelling upon addition of the mitoKATP opener BMS-191095 and were characterized by unchanged matrix volume responses during oxidative phosphorylation [122].

ROMK-less heart mitochondria exhibited a decreased threshold for calcium-triggered PTP opening but molecular details of how the presence of ROMK can de-sensitize PTP towards a calcium increase are missing: the association of ROMK2 with the ATP synthase (see above) might contribute to this effect. Alternatively, mitoKATP opening may slightly depolarize the IMM and reduce the driving force for $\mathrm{Ca}^{2+}$ entry, thereby counteracting mitochondrial $\mathrm{Ca}^{2+}$ overload and subsequent mPTP opening [123]. Altogether, the authors of this seminal work concluded that cardiomyocyte ROMK is not a major component of the cardioprotective mitoKATP channel, although to our knowledge the possibility that other Kir channel-forming subunits undertook the function of ROMK in the KO heart has not been ruled out.

As a last chapter in the "saga" of mitoKATP identification, a mitochondria- specific, ubiquitously expressed coiled-coil domain containing protein, CCDC51, was proposed to form a $\mathrm{K}^{+}$-permeable monovalent cationic pore [124]. The channel formed by recombinant CCDC51 was inhibited by ATP, glibenclamide and 5-hydroxydecanoate and was activated by diazoxide, only when co-assembled with a mitochondrial $\mathrm{ABC}$ protein (ABCB8). The conductance of the CCDC51-ABCB8 complex, reconstituted in proteoliposomes and studied by electrophysiology (planar lipid bilayer), was $57 \mathrm{pS}$ in $100 \mathrm{mM} \mathrm{K}$-gluconate medium. Importantly, using cells where CCDC51 was genetically deleted, it has been demonstrated that this protein controls mitochondrial volume and efficiency of oxidative phosphorylation, as expected for mitoKATP. Moreover, diazoxide-triggered $86 \mathrm{Rb}^{+}$(used as surrogate of $\mathrm{K}^{+}$) influx into isolated energized liver mitochondria was completely abolished in CCDC51less organelles, suggesting that at least in the liver, diazoxide does not trigger $\mathrm{K}^{+}$uptake by acting on ATP synthase or on the complex comprising complexes II and V, ANT, mABC1 and the phosphate carrier or on Kir6.2/Kir6.1 channels. Most importantly, the whole-body 
deletion of CCDC51 almost completely suppressed the cardioprotection that was elicited by the pharmacological preconditioning induced by diazoxide, suggesting again a crucial role for CCDC51 (in complex with ABCB8) in the protective action of diazoxide. In order to correlate these results with mitoKATP channel activities described so far in the IMM from different tissues, it will be very important to characterize by patch clamp the ATP- and diazoxide-dependent activities in the IMM of mitochondria from different CCDC51-KO mouse tissues (a work that is under way in our laboratory).

As a future perspective, one may envision a collaborative effort among chemists, cell biologists, electrophysiologists and cardiologists, to understand if mitoKATP composition can vary depending on the tissue type. A recent study described the synthesis of a mitochondriotropic, triphenylphosphonium-linked [125] variant of the mitoKATP activator spirocyclic benzopyrane F81 and showed that mito-F81 exerted cardioprotective effects at a 10-fold lower dose with respect to the parent compound [126]. Unfortunately, this study did not directly test the inhibitory effect of the modified compound on mitoKATP in electrophysiological experiments nor compared $\mathrm{EC}_{50}$ values of the two compounds for inhibition of $\mathrm{Tl}+$ uptake. Nonetheless, this compound has the advantage of most probably acting prevalently on mitoKATP (and not on PM KATP) and could be used in various cell lines knocked-out for Kir6.2, ROMK, CCDC51, and ANT, as well as in various ATP synthase subunit-knocked down cells. In addition, this compound could also be used for affinity chromatography followed by mass spectrometry to identify the proteins interacting with high affinity. On the other hand, caution should be taken, as $\mathrm{TPP}^{+}$-targeting may modify the original properties of chemicals, decrease their affinity for the target (e.g., [127]) and trigger additional and/or off-target effects as well (e.g., [43,128]).

\section{Future Outlook}

In summary, while huge progress has been made in mitochondrial potassium channels in the last few decades, many questions remain open. A cross-disciplinary effort will likely resolve the mysteries regarding possible plasticity in channel formation, dual (or even multiple) targeting to intracellular membranes, and pharmacological regulation. In addition, recent studies highlighted a differential role for some PM and mitochondrial channels, exploiting mitochondria-targeted drugs. While a thorough characterization of these drugs is mandatory, they may represent a handy pharmacological tool against various diseases (see, e.g., $[126,127,129]$ ).

Administration of organelle-specific drugs is the modern trend to achieve significant therapeutic effects (e.g., [130]). However, the problem of possible off-target effects is certainly the barrier that must be overcome in molecular pharmacology to achieve selective targeting and accumulation in mitochondria [5,131]. In the past few decades, various strategies have been developed to target drugs into the mitochondria. Such strategies involve direct conjugation of a targeting ligand to drugs and/or attachment of the targeting ligand to a nanocarrier [132]. The direct conjugation of the ligand is certainly a valid approach through which drugs can easily reach the mitochondria-it is the simplest and easiest method; however, the conjugation procedure can decrease the biochemical effects within the mitochondria. In the nanocarrier system, on the other hand, the therapeutic effect is not lost because the problem of physical interaction and solubility is solved, but optimization is still a challenge due to the use of many different possible compositions to identify the best nanocarrier. Finally, the administration of thermoresponsive drugs to the mitochondria for cancer therapy has recently been described [133].

Mitochondria-targeted drugs have been extensively studied in clinical applications, and several formulations have been approved by the US Food and Drug Administration and European Medicines Agency for clinical applications in patients with cancer. A brief overview of some major approaches aiming to modulate the Krebs cycle, electron transport chain, anaplerosis, mitoROS release and mitochondria-driven apoptosis in cancer is given in e.g., [134]. 
In terms of future perspectives, hopefully mitochondrial ion channels will become preferred targets not only in the context of cancer but also of other human diseases. To our knowledge, to date, no drugs specifically targeting these channels are in clinical use.

Author Contributions: All authors contributed to the writing of the manuscript. All authors have read and agreed to the published version of the manuscript.

Funding: The work in the laboratory of the authors is financed by the Italian Association for Cancer Research (IG AIRC (IG 2017, Id.20286), FISM/AISM (Prot. 284/18/F14), Telethon (GGP19118) and Italian Ministry of University and Education (PRIN 20174TB8KW_004) and Marie-Curie Seal of Excellence postdoctoral fellowship (to Y.K.).

Acknowledgments: The authors are grateful to all colleagues who participated in the works discussed in this review. We also thank for the support the Italian Association for Cancer Research (IG AIRC (IG 2017, Id.20286), FISM/AISM (Prot. 284/18/F14), Telethon (GGP19118) and Italian Ministry of University and Education (PRIN 20174TB8KW_004) and the Marie-Curie Seal of Excellence project.

Conflicts of Interest: The authors declare that they have no conflict of interest.

\section{References}

1. Mitchell, P. Coupling of Phosphorylation to Electron and Hydrogen Transfer by a Chemi-Osmotic type of Mechanism. Nature 1961, 191, 144-148. [CrossRef] [PubMed]

2. Laskowski, M.; Augustynek, B.; Kulawiak, B.; Koprowski, P.; Bednarczyk, P.; Jarmuszkiewicz, W.; Szewczyk, A. What do we not know about mitochondrial potassium channels? Biochim. Biophys. Acta 2016, 1857, 1247-1257. [CrossRef]

3. Szewczyk, A.; Bednarczyk, P.; Jedraszko, J.; Kampa, R.P.; Koprowski, P.; Krajewska, M.; Kucman, S.; Kulawiak, B.; Laskowski, M.; Rotko, D.; et al. Mitochondrial potassium channels-An overview. Postepy Biochem. 2018, 64, 196-212. [CrossRef]

4. Szteyn, K.; Singh, H. BK(Ca) Channels as Targets for Cardioprotection. Antioxidants 2020, 9, 760. [CrossRef]

5. Wrzosek, A.; Augustynek, B.; Żochowska, M.; Szewczyk, A. Mitochondrial Potassium Channels as Druggable Targets. Biomolecules 2020, 10, 1200. [CrossRef]

6. Checchetto, V.; Leanza, L.; De Stefani, D.; Rizzuto, R.; Gulbins, E.; Szabo, I. Mitochondrial K(+) channels and their implications for disease mechanisms. Pharmacol. Ther. 2021, 227, 107874. [CrossRef] [PubMed]

7. Pereira, O., Jr.; Kowaltowski, A.J. Mitochondrial K(+) Transport: Modulation and Functional Consequences. Molecules 2021, 26, 2935. [CrossRef]

8. Checchetto, V.; Azzolini, M.; Peruzzo, R.; Capitanio, P.; Leanza, L. Mitochondrial potassium channels in cell death. Biochem. Biophys. Res. Commun. 2018, 500, 51-58. [CrossRef]

9. Krabbendam, I.E.; Honrath, B.; Culmsee, C.; Dolga, A.M. Mitochondrial $\mathrm{Ca}(2+)$-activated $\mathrm{K}(+)$ channels and their role in cell life and death pathways. Cell Calcium. 2018, 69, 101-111. [CrossRef] [PubMed]

10. Costa, R.; Peruzzo, R.; Bachmann, M.; Monta, G.D.; Vicario, M.; Santinon, G.; Mattarei, A.; Moro, E.; Quintana- Cabrera, R.; Scorrano, L.; et al. Impaired Mitochondrial ATP Production Downregulates Wnt Signaling via ER Stress Induction. Cell Rep. 2019, 28, 1949-1960. [CrossRef] [PubMed]

11. Frankenreiter, S.; Bednarczyk, P.; Kniess, A.; Bork, N.I.; Straubinger, J.; Koprowski, P.; Wrzosek, A.; Mohr, E.; Logan, A.; Murphy, M.P.; et al. cGMP-Elevating Compounds and Ischemic Conditioning Provide Cardioprotection Against Ischemia and Reperfusion Injury via Cardiomyocyte-Specific BK Channels. Circulation 2017, 136, 2337-2355. [CrossRef]

12. Bachmann, M.; Pontarin, G.; Szabo, I. The Contribution of Mitochondrial Ion Channels to Cancer Development and Progression. Cell. Physiol. Biochem. Int. J. Exp. Cell. Physiol. Biochem. Pharmacol. 2019, 53, 63-78. [CrossRef]

13. Hausenloy, D.J.; Schulz, R.; Girao, H.; Kwak, B.R.; De Stefani, D.; Rizzuto, R.; Bernardi, P.; Di Lisa, F. Mitochondrial ion channels as targets for cardioprotection. J. Cell. Mol. Med. 2020, 24, 7102-7114. [CrossRef]

14. Ponnalagu, D.; Singh, H. Insights into the Role of Mitochondrial Ion Channels in Inflammatory Response. Front. Physiol. 2020, 11, 258. [CrossRef]

15. Garlid, K.D. Cation transport in mitochondria-The potassium cycle. Biochim. Biophys. Acta (BBA)-Bioenerg. 1996, 1275, 123-126. [CrossRef]

16. Shoshan-Barmatz, V.; Shteinfer-Kuzmine, A.; Verma, A. VDAC1 at the Intersection of Cell Metabolism, Apoptosis, and Diseases. Biomolecules 2020, 10, 1485. [CrossRef]

17. De Pinto, V. Renaissance of VDAC: New Insights on a Protein Family at the Interface between Mitochondria and Cytosol. Biomolecules 2021, 11, 107. [CrossRef] [PubMed]

18. Szabo, I.; Zoratti, M. Mitochondrial channels: Ion fluxes and more. Physiol. Rev. 2014, 94, 519-608. [CrossRef] [PubMed]

19. De Pinto, V.; Reina, S.; Gupta, A.; Messina, A.; Mahalakshmi, R. Role of cysteines in mammalian VDAC isoforms' function. Biochim. Biophys. Acta (BBA)-Bioenerg. 2016, 1857, 1219-1227. [CrossRef] 
20. Fieni, F.; Parkar, A.; Misgeld, T.; Kerschensteiner, M.; Lichtman, J.W.; Pasinelli, P.; Trotti, D. Voltage-dependent inwardly rectifying potassium conductance in the outer membrane of neuronal mitochondria. J. Biol. Chem. 2010, 285, 27411-27417. [CrossRef] [PubMed]

21. Báthori, G.; Szabó, I.; Schmehl, I.; Tombola, F.; Messina, A.; De Pinto, V.; Zoratti, M. Novel aspects of the electrophysiology of mitochondrial porin. Biochem. Biophys. Res. Commun. 1998, 243, 258-263. [CrossRef] [PubMed]

22. De Stefani, D.; Bononi, A.; Romagnoli, A.; Messina, A.; De Pinto, V.; Pinton, P.; Rizzuto, R. VDAC1 selectively transfers apoptotic $\mathrm{Ca}^{2+}$ signals to mitochondria. Cell Death Differ. 2012, 19, 267-273. [CrossRef]

23. Shimizu, H.; Schredelseker, J.; Huang, J.; Lu, K.; Naghdi, S.; Lu, F.; Franklin, S.; Fiji, H.D.; Wang, K.; Zhu, H.; et al. Mitochondrial $\mathrm{Ca}(2+)$ uptake by the voltage-dependent anion channel 2 regulates cardiac rhythmicity. eLife 2015, 4, e04801. [CrossRef]

24. Gergalova, G.; Lykhmus, O.; Kalashnyk, O.; Koval, L.; Chernyshov, V.; Kryukova, E.; Tsetlin, V.; Komisarenko, S.; Skok, M. Mitochondria express alpha7 nicotinic acetylcholine receptors to regulate $\mathrm{Ca}^{2+}$ accumulation and cytochrome c release: Study on isolated mitochondria. PLoS ONE 2012, 7, e31361. [CrossRef]

25. Inoue, I.; Nagase, H.; Kishi, K.; Higuti, T. ATP-sensitive $\mathrm{K}^{+}$channel in the mitochondrial inner membrane. Nature 1991, 352, 244-247. [CrossRef]

26. Szabo, I.; Bock, J.; Jekle, A.; Soddemann, M.; Adams, C.; Lang, F.; Zoratti, M.; Gulbins, E. A novel potassium channel in lymphocyte mitochondria. J. Biol. Chem. 2005, 280, 12790-12798. [CrossRef]

27. Bednarczyk, P.; Kowalczyk, J.E.; Beręsewicz, M.; Dołowy, K.; Szewczyk, A.; Zabłocka, B. Identification of a voltage-gated potassium channel in gerbil hippocampal mitochondria. Biochem. Biophys. Res. Commun. 2010, 397, 614-620. [CrossRef]

28. De Marchi, U.; Sassi, N.; Fioretti, B.; Catacuzzeno, L.; Cereghetti, G.M.; Szabo, I.; Zoratti, M. Intermediate conductance Ca ${ }^{2+}{ }_{-}$ activated potassium channel (KCa3.1) in the inner mitochondrial membrane of human colon cancer cells. Cell Calcium. 2009, 45, 509-516. [CrossRef] [PubMed]

29. Siemen, D.; Loupatatzis, C.; Borecky, J.; Gulbins, E.; Lang, F. Ca ${ }^{2+}$-Activated K Channel of the BK-Type in the Inner Mitochondrial Membrane of a Human Glioma Cell Line. Biochem. Biophys. Res. Commun. 1999, 257, 549-554. [CrossRef]

30. Singh, H.; Stefani, E.; Toro, L. Intracellular BK(Ca) (iBK(Ca)) channels. J. Physiol. 2012, 590, 5937-5947. [CrossRef] [PubMed]

31. Dolga, A.M.; Netter, M.F.; Perocchi, F.; Doti, N.; Meissner, L.; Tobaben, S.; Grohm, J.; Zischka, H.; Plesnila, N.; Decher, N.; et al. Mitochondrial small conductance SK2 channels prevent glutamate-induced oxytosis and mitochondrial dysfunction. J. Biol. Chem. 2013, 288, 10792-10804. [CrossRef]

32. Laskowski, M.; Augustynek, B.; Bednarczyk, P.; Żochowska, M.; Kalisz, J.; O’Rourke, B.; Szewczyk, A.; Kulawiak, B. SingleChannel Properties of the ROMK-Pore-Forming Subunit of the Mitochondrial ATP-Sensitive Potassium Channel. Int. J. Mol. Sci. 2019, 20, 5323. [CrossRef] [PubMed]

33. Toczyłowska-Mamińska, R.; Olszewska, A.; Laskowski, M.; Bednarczyk, P.; Skowronek, K.; Szewczyk, A. Potassium channel in the mitochondria of human keratinocytes. J. Investig. Dermatol. 2014, 134, 764-772. [CrossRef] [PubMed]

34. León-Aparicio, D.; Salvador, C.; Aparicio-Trejo, O.E.; Briones-Herrera, A.; Pedraza-Chaverri, J.; Vaca, L.; Sampieri, A.; Padilla-Flores, T.; López-González, Z.; León-Contreras, J.C.; et al. Novel Potassium Channels in Kidney Mitochondria: The Hyperpolarization-Activated and Cyclic Nucleotide-Gated HCN Channels. Int. J. Mol. Sci. 2019, 20, 4995. [CrossRef] [PubMed]

35. Padilla-Flores, T.; López-González, Z.; Vaca, L.; Aparicio-Trejo, O.E.; Briones-Herrera, A.; Riveros-Rosas, H.; Pedraza-Chaverri, J.; León-Aparicio, D.; Salvador, C.; Sampieri, A.; et al. "Funny" channels in cardiac mitochondria modulate membrane potential and oxygen consumption. Biochem. Biophys. Res. Commun. 2020, 524, 1030-1036. [CrossRef]

36. Bednarczyk, P.; Kampa, R.P.; Gałecka, S.; Sęk, A.; Walewska, A.; Koprowski, P. Patch-Clamp Recording of the Activity of Ion Channels in the Inner Mitochondrial Membrane. Methods Mol. Biol. 2021, 2276, 235-248. [CrossRef]

37. Kirichok, Y.; Krapivinsky, G.; Clapham, D.E. The mitochondrial calcium uniporter is a highly selective ion channel. Nature 2004, 427, 360-364. [CrossRef]

38. Testai, L.; Barrese, V.; Soldovieri, M.V.; Ambrosino, P.; Martelli, A.; Vinciguerra, I.; Miceli, F.; Greenwood, I.A.; Curtis, M.J.; Breschi, M.C.; et al. Expression and function of Kv7.4 channels in rat cardiac mitochondria: Possible targets for cardioprotection. Cardiovasc. Res. 2016, 110, 40-50. [CrossRef]

39. Leanza, L.; Zoratti, M.; Gulbins, E.; Szabo, I. Induction of apoptosis in macrophages via Kv1.3 and Kv1.5 potassium channels. Curr. Med. Chem. 2012, 19, 5394-5404. [CrossRef]

40. Capera, J.; Pérez-Verdaguer, M.; Peruzzo, R.; Navarro-Pérez, M.; Martínez-Pinna, J.; Alberola-Die, A.; Morales, A.; Leanza, L.; Szabó, I.; Felipe, A. A novel mitochondrial Kv1.3-caveolin axis controls cell survival and apoptosis. eLife 2021, 10, e69099. [CrossRef]

41. Thevarajan, I.; Zolkiewski, M.; Zolkiewska, A. Human CLPB forms ATP-dependent complexes in the mitochondrial intermembrane space. Int. J. Biochem. Cell Biol. 2020, 127, 105841. [CrossRef]

42. Capera, J.; Serrano-Novillo, C.; Navarro-Pérez, M.; Cassinelli, S.; Felipe, A. The Potassium Channel Odyssey: Mechanisms of Traffic and Membrane Arrangement. Int. J. Mol. Sci. 2019, 20, 734. [CrossRef]

43. Peruzzo, R.; Mattarei, A.; Azzolini, M.; Becker-Flegler, K.A.; Romio, M.; Rigoni, G.; Carrer, A.; Biasutto, L.; Parrasia, S.; Kadow, S.; et al. Insight into the mechanism of cytotoxicity of membrane-permeant psoralenic Kv1.3 channel inhibitors by chemical dissection of a novel member of the family. Redox Biol. 2020, 37, 101705. [CrossRef] 
44. Styles, F.L.; Al-Owais, M.M.; Scragg, J.L.; Chuntharpursat-Bon, E.; Hettiarachchi, N.T.; Lippiat, J.D.; Minard, A.; Bon, R.S.; Porter, K.; Sukumar, P.; et al. Kv1.3 voltage-gated potassium channels link cellular respiration to proliferation through a non-conducting mechanism. Cell Death Dis. 2021, 12, 372. [CrossRef]

45. Bednarczyk, P.; Wieckowski, M.R.; Broszkiewicz, M.; Skowronek, K.; Siemen, D.; Szewczyk, A. Putative Structural and Functional Coupling of the Mitochondrial BK Channel to the Respiratory Chain. PLoS ONE 2013, 8, e68125. [CrossRef]

46. Ardehali, H.; Chen, Z.; Ko, Y.; Mejía-Alvarez, R.; Marbán, E. Multiprotein complex containing succinate dehydrogenase confers mitochondrial ATP-sensitive $\mathrm{K}^{+}$channel activity. Proc. Natl. Acad. Sci. USA 2004, 101, 11880-11885. [CrossRef]

47. Wojtovich, A.P.; Brookes, P.S. The endogenous mitochondrial complex II inhibitor malonate regulates mitochondrial ATP-sensitive potassium channels: Implications for ischemic preconditioning. Biochim. Biophys. Acta (BBA)-Bioenerg. 2008, 1777, 882-889. [CrossRef] [PubMed]

48. Foster, D.B.; Ho, A.S.; Rucker, J.; Garlid, A.O.; Chen, L.; Sidor, A.; Garlid, K.D.; O’Rourke, B. Mitochondrial ROMK channel is a molecular component of mitoK(ATP). Circ. Res. 2012, 111, 446-454. [CrossRef] [PubMed]

49. Yao, J.; McHedlishvili, D.; McIntire, W.E.; Guagliardo, N.A.; Erisir, A.; Coburn, C.A.; Santarelli, V.P.; Bayliss, D.A.; Barrett, P.Q. Functional TASK-3-Like Channels in Mitochondria of Aldosterone-Producing Zona Glomerulosa Cells. Hypertension 2017, 70, 347-356. [CrossRef] [PubMed]

50. Kono, Y.; Horie, M.; Takano, M.; Otani, H.; Xie, L.H.; Akao, M.; Tsuji, K.; Sasayama, S. The properties of the Kir6.1-6.2 tandem channel co-expressed with SUR2A. Pflug. Arch. Eur. J. Physiol. 2000, 440, 692-698. [CrossRef]

51. Tang, G.; Wu, L.; Liang, W.; Wang, R. Direct stimulation of K(ATP) channels by exogenous and endogenous hydrogen sulfide in vascular smooth muscle cells. Mol. Pharmacol. 2005, 68, 1757-1764. [CrossRef] [PubMed]

52. Noma, A. ATP-regulated $\mathrm{K}^{+}$channels in cardiac muscle. Nature 1983, 305, 147-148. [CrossRef] [PubMed]

53. Isomoto, S.; Kondo, C.; Yamada, M.; Matsumoto, S.; Higashiguchi, O.; Horio, Y.; Matsuzawa, Y.; Kurachi, Y. A Novel Sulfonylurea Receptor Forms with BIR (Kir6.2) a Smooth Muscle Type ATP-sensitive $\mathrm{K}^{+}$Channel. J. Biol. Chem. 1996, 271, 24321-24324. [CrossRef] [PubMed]

54. Okuyama, Y.; Yamada, M.; Kondo, C.; Satoh, E.; Isomoto, S.; Shindo, T.; Horio, Y.; Kitakaze, M.; Hori, M.; Kurachi, Y. The effects of nucleotides and potassium channel openers on the SUR2A/Kir6.2 complex $\mathrm{K}^{+}$channel expressed in a mammalian cell line, HEK293T cells. Pflügers Arch. 1998, 435, 595-603. [CrossRef] [PubMed]

55. Standen, N.B.; Quayle, J.M.; Davies, N.W.; Brayden, J.E.; Huang, Y.; Nelson, M.T. Hyperpolarizing vasodilators activate ATP-sensitive $\mathrm{K}^{+}$channels in arterial smooth muscle. Science 1989, 245, 177. [CrossRef] [PubMed]

56. Dahlem, Y.A.; Horn, T.F.; Buntinas, L.; Gonoi, T.; Wolf, G.; Siemen, D. The human mitochondrial KATP channel is modulated by calcium and nitric oxide: A patch-clamp approach. Biochim. Biophys. Acta (BBA)-Bioenerg. 2004, 1656, 46-56. [CrossRef] [PubMed]

57. Kampa, R.P.; Kicinska, A.; Jarmuszkiewicz, W.; Pasikowska-Piwko, M.; Dolegowska, B.; Debowska, R.; Szewczyk, A.; Bednarczyk, P. Naringenin as an opener of mitochondrial potassium channels in dermal fibroblasts. Exp. Dermatol. 2019, 28, 543-550. [CrossRef]

58. Pahapill, P.A.; Schlichter, L.C. Modulation of potassium channels in intact human T lymphocytes. J. Physiol. 1992, 445, 407-430. [CrossRef]

59. Marty, A. Ca-dependent K channels with large unitary conductance in chromaffin cell membranes. Nature 1981, 291, 497-500. [CrossRef]

60. Pallotta, B.S.; Magleby, K.L.; Barrett, J.N. Single channel recordings of $\mathrm{Ca}^{2+}$-activated $\mathrm{K}^{+}$currents in rat muscle cell culture. Nature 1981, 293, 471-474. [CrossRef]

61. Kravenska, Y.; Nieznanska, H.; Nieznanski, K. Prion protein protects the large-conductance calcium-activated potassium channel from the inhibitory effect of Tau protein. 2021. submitted.

62. Latorre, R.; Morera, F.J.; Zaelzer, C. SYMPOSIUM REVIEW: Allosteric interactions and the modular nature of the voltage- and $\mathrm{Ca}^{2+}$-activated (BK) channel. J. Physiol. 2010, 588, 3141-3148. [CrossRef] [PubMed]

63. Soltysinska, E.; Bentzen, B.H.; Barthmes, M.; Hattel, H.; Thrush, A.B.; Harper, M.-E.; Qvortrup, K.; Larsen, F.J.; Schiffer, T.A.; Losa-Reyna, J.; et al. KCNMA1 encoded cardiac BK channels afford protection against ischemia- reperfusion injury. PLoS ONE 2014, 9, e103402. [CrossRef] [PubMed]

64. Xu, W.; Liu, Y.; Wang, S.; McDonald, T.; Van Eyk, J.E.; Sidor, A.; Rourke, B. Cytoprotective Role of Ca ${ }^{2+}-$ Activated K $^{+}$Channels in the Cardiac Inner Mitochondrial Membrane. Science 2002, 298, 1029. [CrossRef] [PubMed]

65. Kicinska, A.; Augustynek, B.; Kulawiak, B.; Jarmuszkiewicz, W.; Szewczyk, A.; Bednarczyk, P. A large- conductance calciumregulated $\mathrm{K}^{+}$channel in human dermal fibroblast mitochondria. Biochem. J. 2016, 473, 4457-4471. [CrossRef]

66. Balderas, E.; Torres, N.S.; Rosa-Garrido, M.; Chaudhuri, D.; Toro, L.; Stefani, E.; Olcese, R. MitoBKCa channel is functionally associated with its regulatory $\beta 1$ subunit in cardiac mitochondria. J. Physiol. 2019, 597, 3817-3832. [CrossRef]

67. Kicinska, A.; Kampa, R.P.; Daniluk, J.; Sek, A.; Jarmuszkiewicz, W.; Szewczyk, A.; Bednarczyk, P. Regulation of the Mitochondrial BK(Ca) Channel by the Citrus Flavonoid Naringenin as a Potential Means of Preventing Cell Damage. Mollecules 2020, $25,3010$. [CrossRef]

68. Kravenska, Y.; Nieznanska, H.; Nieznanski, K.; Lukyanetz, E.; Szewczyk, A.; Koprowski, P. The monomers, oligomers, and fibrils of amyloid- $\beta$ inhibit the activity of mitoBKCa channels by a membrane-mediated mechanism. Biochim. Biophys. Acta (BBA)-Biomembr. 2020, 1862, 183337. [CrossRef] 
69. Grygorczyk, R.; Schwarz, W.; Passow, H. Ca ${ }^{2+}$-activated $\mathrm{K}^{+}$channels in human red cells. Comparison of single- channel currents with ion fluxes. Biophys. J. 1984, 45, 693-698. [CrossRef]

70. Logsdon, N.J.; Kang, J.; Togo, J.A.; Christian, E.P.; Aiyar, J. A novel gene, hKCa4, encodes the calcium-activated potassium channel in human T lymphocytes. J. Biol. Chem. 1997, 272, 32723-32726. [CrossRef] [PubMed]

71. Chen, P.C.; Ruan, J.S.; Wu, S.N. Evidence of Decreased Activity in Intermediate-Conductance Calcium-Activated Potassium Channels During Retinoic Acid-Induced Differentiation in Motor Neuron-Like NSC-34 Cells. Cell. Physiol. Biochem. 2018, 48, 2374-2388. [CrossRef]

72. Ishii, T.M.; Silvia, C.; Hirschberg, B.; Bond, C.T.; Adelman, J.P.; Maylie, J. A human intermediate conductance calcium-activated potassium channel. Proc. Natl. Acad. Sci. USA 1997, 94, 11651-11656. [CrossRef]

73. Koselski, M.; Olszewska, A.; Hordyjewska, A.; Malecka-Massalska, T.; Trebacz, K. Three types of ion channels in the cell membrane of mouse fibroblasts. Physiol. Res. 2017, 66, 63-73. [CrossRef]

74. Light, D.B.; Van Eenenaam, D.P.; Sorenson, R.L.; Levitt, D.G. Potassium-selective ion channels in a transformed insulin-secreting cell line. J. Membr. Biol. 1987, 95, 63-72. [CrossRef] [PubMed]

75. Palmer, L.G.; Frindt, G. Regulation of apical K channels in rat cortical collecting tubule during changes in dietary K intake. Am. J. Physiol. 1999, 277, F805-F812. [CrossRef] [PubMed]

76. Lu, M.; Leng, Q.; Egan, M.E.; Caplan, M.J.; Boulpaep, E.L.; Giebisch, G.H.; Hebert, S.C. CFTR is required for PKA- regulated ATP sensitivity of Kir1.1 potassium channels in mouse kidney. J. Clin. Investig. 2006, 116, 797-807. [CrossRef] [PubMed]

77. Ho, K.; Nichols, C.G.; Lederer, W.J.; Lytton, J.; Vassilev, P.M.; Kanazirska, M.V.; Hebert, S.C. Cloning and expression of an inwardly rectifying ATP-regulated potassium channel. Nature 1993, 362, 31-38. [CrossRef]

78. Ashmole, I.; Vavoulis, D.V.; Stansfeld, P.J.; Mehta, P.R.; Feng, J.F.; Sutcliffe, M.J.; Stanfield, P.R. The response of the tandem pore potassium channel TASK-3 (K2P9.1) to voltage: Gating at the cytoplasmic mouth. J. Physiol. 2009, 587, 4769-4783. [CrossRef]

79. Kim, Y.; Bang, H.; Kim, D. TASK-3, a new member of the tandem pore K(+) channel family. J. Biol. Chem. 2000, 275, 9340-9347. [CrossRef]

80. DiFrancesco, D. Characterization of single pacemaker channels in cardiac sino-atrial node cells. Nature 1986, 324, 470-473. [CrossRef]

81. Liu, C.; Xie, C.; Grant, K.; Su, Z.; Gao, W.; Liu, Q.; Zhou, L. Patch-clamp fluorometry-based channel counting to determine HCN channel conductance. J. Gen. Physiol. 2016, 148, 65-76. [CrossRef]

82. Garlid, K.D.; Paucek, P. The mitochondrial potassium cycle. IUBMB Life 2001, 52, 153-158. [CrossRef]

83. Austin, S.; Nowikovsky, K. LETM1: Essential for Mitochondrial Biology and Cation Homeostasis? Trends Biochem. Sci. 2019, 44, 648-658. [CrossRef]

84. Nowikovsky, K.; Froschauer, E.M.; Zsurka, G.; Samaj, J.; Reipert, S.; Kolisek, M.; Wiesenberger, G.; Schweyen, R.J. The LETM1/YOL027 gene family encodes a factor of the mitochondrial $\mathrm{K}^{+}$homeostasis with a potential role in the Wolf-Hirschhorn syndrome. J. Biol. Chem. 2004, 279, 30307-30315. [CrossRef]

85. Jiang, D.; Zhao, L.; Clish, C.B.; Clapham, D.E. Letm1, the mitochondrial $\mathrm{Ca}^{2+} / \mathrm{H}^{+}$antiporter, is essential for normal glucose metabolism and alters brain function in Wolf-Hirschhorn syndrome. Proc. Natl. Acad. Sci. USA 2013, 110, E2249-E2254. [CrossRef]

86. Tsai, M.F.; Jiang, D.; Zhao, L.; Clapham, D.; Miller, C. Functional reconstitution of the mitochondrial Ca ${ }^{2+} / \mathrm{H}^{+}$antiporter Letm1. J. Gen. Physiol. 2014, 143, 67-73. [CrossRef] [PubMed]

87. Austin, S.; Tavakoli, M.; Pfeiffer, C.; Seifert, J.; Mattarei, A.; De Stefani, D.; Zoratti, M.; Nowikovsky, K. LETM1- Mediated K(+) and $\mathrm{Na}(+)$ Homeostasis Regulates Mitochondrial Ca(2+) Efflux. Front. Physiol. 2017, 8, 839. [CrossRef]

88. Natarajan, G.K.; Glait, L.; Mishra, J.; Stowe, D.F.; Camara, A.K.S.; Kwok, W.M. Total Matrix Ca(2+) Modulates Ca(2+) Efflux via the $\mathrm{Ca}(2+) / \mathrm{H}(+)$ Exchanger in Cardiac Mitochondria. Front. Physiol. 2020, 11, 510600. [CrossRef] [PubMed]

89. Dos Santos, G.R.R.; Rezende Leite, A.C.; Lander, N.; Chiurillo, M.A.; Vercesi, A.E.; Docampo, R. Trypanosoma cruzi Letm1 is involved in mitochondrial $\mathrm{Ca}(2+)$ transport, and is essential for replication, differentiation, and host cell invasion. FASEB J. Off. Publ. Fed. Am. Soc. Exp. Biol. 2021, 35, e21685. [CrossRef]

90. Nakamura, S.; Matsui, A.; Akabane, S.; Tamura, Y.; Hatano, A.; Miyano, Y.; Omote, H.; Kajikawa, M.; Maenaka, K.; Moriyama, Y.; et al. The mitochondrial inner membrane protein LETM1 modulates cristae organization through its LETM domain. Commun. Biol. 2020, 3, 99. [CrossRef] [PubMed]

91. Dimmer, K.S.; Navoni, F.; Casarin, A.; Trevisson, E.; Endele, S.; Winterpacht, A.; Salviati, L.; Scorrano, L. LETM1, deleted in Wolf-Hirschhorn syndrome is required for normal mitochondrial morphology and cellular viability. Hum. Mol. Genet. 2008, 17, 201-214. [CrossRef]

92. Pipatpolkai, T.; Usher, S.; Stansfeld, P.J.; Ashcroft, F.M. New insights into K(ATP) channel gene mutations and neonatal diabetes mellitus. Nat. Rev. Endocrinol. 2020, 16, 378-393. [CrossRef] [PubMed]

93. Tinker, A.; Aziz, Q.; Li, Y.; Specterman, M. ATP-Sensitive Potassium Channels and Their Physiological and Pathophysiological Roles. Compr. Physiol. 2018, 8, 1463-1511. [CrossRef] [PubMed]

94. Sorgato, M.C.; Keller, B.U.; Stühmer, W. Patch-clamping of the inner mitochondrial membrane reveals a voltage- dependent ion channel. Nature 1987, 330, 498-500. [CrossRef]

95. Zhang, H.; Bolton, T.B. Activation by intracellular GDP, metabolic inhibition and pinacidil of a glibenclamide- sensitive K-channel in smooth muscle cells of rat mesenteric artery. Br. J. Pharmacol. 1995, 114, 662-672. [CrossRef] 
96. Grover, G.J.; McCullough, J.R.; Henry, D.E.; Conder, M.L.; Sleph, P.G. Anti-ischemic effects of the potassium channel activators pinacidil and cromakalim and the reversal of these effects with the potassium channel blocker glyburide. J. Pharmacol. Exp. Ther. 1989, 251, 98.

97. Xu, X.; Tsai, T.D.; Lee, K.S. A specific activator of the ATP-inhibited $\mathrm{K}^{+}$channels in guinea pig ventricular cells. J. Pharmacol. Exp. Ther. 1993, 266, 978.

98. Ashcroft, F.M.; Gribble, F.M. New windows on the mechanism of action of KATP channel openers. Trends Pharmacol. Sci. 2000, 21, 439-445. [CrossRef]

99. Baukrowitz, T.; Fakler, B. KATP channels gated by intracellular nucleotides and phospholipids. Eur. J. Biochem. 2000, 267, 5842-5848. [CrossRef]

100. Moreau, C.; Jacquet, H.; Prost, A.-L.; D'Hahan, N.; Vivaudou, M. The molecular basis of the specificity of action of KATP channel openers. EMBO J. 2000, 19, 6644-6651. [CrossRef]

101. Sato, T.; Sasaki, N.; Seharaseyon, J.; O’Rourke, B.; Marbán, E. Selective Pharmacological Agents Implicate Mitochondrial but Not Sarcolemmal KATP Channels in Ischemic Cardioprotection. Circulation 2000, 101, 2418-2423. [CrossRef] [PubMed]

102. Moreau, C.; Prost, A.-L.; Dérand, R.; Vivaudou, M. SUR, ABC proteins targeted by KATP channel openers. J. Mol. Cell. Cardiol. 2005, 38, 951-963. [CrossRef]

103. Gögelein, H.; Hartung, J.; Englert, H.C.; Schölkens, B.A. HMR 1883, a novel cardioselective inhibitor of the ATP- sensitive potassium channel. Part I: Effects on cardiomyocytes, coronary flow and pancreatic beta-cells. J. Pharmacol. Exp. Ther. 1998, 286, 1453-1464.

104. Russ, U.; Lange, U.; Löffler-Walz, C.; Hambrock, A.; Quast, U. Interaction of the sulfonylthiourea HMR 1833 with sulfonylurea receptors and recombinant ATP-sensitive $\mathrm{K}(+)$ channels: Comparison with glibenclamide. J. Pharmacol. Exp. Ther. 2001, $299,1049$. [PubMed]

105. Bednarczyk, P.; Kicinska, A.; Laskowski, M.; Kulawiak, B.; Kampa, R.; Walewska, A.; Krajewska, M.; Jarmuszkiewicz, W.; Szewczyk, A. Evidence for a mitochondrial ATP-regulated potassium channel in human dermal fibroblasts. Biochim. Biophys. Acta Bioenerg. 2018, 1859, 309-318. [CrossRef] [PubMed]

106. Liu, D.; Lu, C.; Wan, R.; Auyeung, W.W.; Mattson, M.P. Activation of mitochondrial ATP-dependent potassium channels protects neurons against ischemia-induced death by a mechanism involving suppression of Bax translocation and cytochrome c release. $J$. Cereb. Blood Flow Metab. Off. J. Int. Soc. Cereb. Blood Flow Metab. 2002, 22, 431-443. [CrossRef] [PubMed]

107. Peng, K.; Hu, J.; Xiao, J.; Dan, G.; Yang, L.; Ye, F.; Zou, Z.; Cao, J.; Sai, Y. Mitochondrial ATP-sensitive potassium channel regulates mitochondrial dynamics to participate in neurodegeneration of Parkinson's disease. Biochim. Biophys. Acta Mol. Basis Dis. 2018, 1864, 1086-1103. [CrossRef]

108. Liu, D.; Pitta, M.; Lee, J.H.; Ray, B.; Lahiri, D.K.; Furukawa, K.; Mughal, M.; Jiang, H.; Villarreal, J.; Cutler, R.G.; et al. The KATP channel activator diazoxide ameliorates amyloid- $\beta$ and tau pathologies and improves memory in the 3xTgAD mouse model of Alzheimer's disease. J. Alzheimer's Dis. JAD 2010, 22, 443-457. [CrossRef]

109. Kowaltowski, A.J.; Maciel, E.N.; Fornazari, M.; Castilho, R.F. Diazoxide protects against methylmalonate-induced neuronal toxicity. Exp. Neurol. 2006, 201, 165-171. [CrossRef]

110. Dröse, S.; Brandt, U.; Hanley, P.J. $\mathrm{K}^{+}$-independent actions of diazoxide question the role of inner membrane KATP channels in mitochondrial cytoprotective signaling. J. Biol. Chem. 2006, 281, 23733-23739. [CrossRef]

111. Gavali, J.T.; Carrillo, E.D.; García, M.C.; Sánchez, J.A. The mitochondrial K-ATP channel opener diazoxide upregulates STIM1 and Orai1 via ROS and the MAPK pathway in adult rat cardiomyocytes. Cell Biosci. 2020, 10, 96. [CrossRef]

112. Wojtovich, A.P.; Urciuoli, W.R.; Chatterjee, S.; Fisher, A.B.; Nehrke, K.; Brookes, P.S. Kir6.2 is not the mitochondrial KATP channel but is required for cardioprotection by ischemic preconditioning. Am. J. Physiol. Heart Circ. Physiol. 2013, 304, H1439-H1445. [CrossRef]

113. Bertholet, A.M.; Chouchani, E.T.; Kazak, L.; Angelin, A.; Fedorenko, A.; Long, J.Z.; Vidoni, S.; Garrity, R.; Cho, J.; Terada, N.; et al. $\mathrm{H}(+)$ transport is an integral function of the mitochondrial ADP/ATP carrier. Nature 2019, 571, 515-520. [CrossRef]

114. Urbani, A.; Giorgio, V.; Carrer, A.; Franchin, C.; Arrigoni, G.; Jiko, C.; Abe, K.; Maeda, S.; Shinzawa-Itoh, K.; Bogers, J.F.M.; et al. Purified F-ATP synthase forms a $\mathrm{Ca}(2+)$-dependent high-conductance channel matching the mitochondrial permeability transition pore. Nat. Commun. 2019, 10, 4341. [CrossRef] [PubMed]

115. Juhaszova, M.; Kobrinsky, E.; Zorov, D.B.; Nuss, H.B.; Yaniv, Y.; Fishbein, K.W.; de Cabo, R.; Montoliu, L.; Gabelli, S.B.; Aon, M.A.; et al. ATP synthase $\mathrm{K}^{+}$- and $\mathrm{H}^{+}$-flux drive ATP synthesis and enable mitochondrial $\mathrm{K}^{+}$-uniporter function. bioRxiv 2019, 355776, preprint. [CrossRef]

116. Contessi, S.; Metelli, G.; Mavelli, I.; Lippe, G. Diazoxide affects the IF1 inhibitor protein binding to F1 sector of beef heart F0F1ATPsynthase. Biochem. Pharmacol. 2004, 67, 1843-1851. [CrossRef] [PubMed]

117. Antoniel, M.; Jones, K.; Antonucci, S.; Spolaore, B.; Fogolari, F.; Petronilli, V.; Giorgio, V.; Carraro, M.; Di Lisa, F.; Forte, M.; et al. The unique histidine in OSCP subunit of F-ATP synthase mediates inhibition of the permeability transition pore by acidic $\mathrm{pH}$. EMBO Rep. 2018, 19, 257-268. [CrossRef]

118. Carraro, M.; Checchetto, V.; Sartori, G.; Kucharczyk, R.; di Rago, J.P.; Minervini, G.; Franchin, C.; Arrigoni, G.; Giorgio, V.; Petronilli, V.; et al. High-Conductance Channel Formation in Yeast Mitochondria is Mediated by F- ATP Synthase e and $g$ Subunits. Cell. Physiol. Biochem. Int. J. Exp. Cell. Physiol. Biochem. Pharmacol. 2018, 50, 1840-1855. [CrossRef] 
119. Mnatsakanyan, N.; Llaguno, M.C.; Yang, Y.; Yan, Y.; Weber, J.; Sigworth, F.J.; Jonas, E.A. A mitochondrial megachannel resides in monomeric $\mathrm{F}(1) \mathrm{F}(\mathrm{O})$ ATP synthase. Nat. Commun. 2019, 10, 5823. [CrossRef] [PubMed]

120. Neginskaya, M.A.; Solesio, M.E.; Berezhnaya, E.V.; Amodeo, G.F.; Mnatsakanyan, N.; Jonas, E.A.; Pavlov, E.V. ATP Synthase C-Subunit-Deficient Mitochondria Have a Small Cyclosporine A-Sensitive Channel, but Lack the Permeability Transition Pore. Cell Rep. 2019, 26, 11-17. [CrossRef]

121. Krajewska, M.; Koprowski, P. Solubilization, purification, and functional reconstitution of human ROMK potassium channel in copolymer styrene-maleic acid (SMA) nanodiscs. Biochim. Biophys. Acta Biomembr. 2021, 1863, 183555. [CrossRef]

122. Papanicolaou, K.N.; Ashok, D.; Liu, T.; Bauer, T.M.; Sun, J.; Li, Z.; da Costa, E.; D'Orleans, C.C.; Nathan, S.; Lefer, D.J.; et al. Global knockout of ROMK potassium channel worsens cardiac ischemia-reperfusion injury but cardiomyocyte-specific knockout does not: Implications for the identity of mitoKATP. J. Mol. Cell. Cardiol. 2020, 139, 176-189. [CrossRef]

123. Holmuhamedov, E.L.; Wang, L.; Terzic, A. ATP-sensitive $\mathrm{K}^{+}$channel openers prevent $\mathrm{Ca}^{2+}$ overload in rat cardiac mitochondria. J. Physiol. 1999, 519 Pt 2, 347-360. [CrossRef]

124. Paggio, A.; Checchetto, V.; Campo, A.; Menabo, R.; Di Marco, G.; Di Lisa, F.; Szabo, I.; Rizzuto, R.; De Stefani, D. Identification of an ATP-sensitive potassium channel in mitochondria. Nature 2019, 572, 609-613. [CrossRef] [PubMed]

125. Smith, R.A.; Hartley, R.C.; Murphy, M.P. Mitochondria-targeted small molecule therapeutics and probes. Antioxid. Redox Signal. 2011, 15, 3021-3038. [CrossRef]

126. Testai, L.; Sestito, S.; Martelli, A.; Gorica, E.; Flori, L.; Calderone, V.; Rapposelli, S. Synthesis and pharmacological characterization of mitochondrial K(ATP) channel openers with enhanced mitochondriotropic effects. Bioorganic Chem. 2021, 107, 104572. [CrossRef]

127. Leanza, L.; Romio, M.; Becker, K.A.; Azzolini, M.; Trentin, L.; Manago, A.; Venturini, E.; Zaccagnino, A.; Mattarei, A.; Carraretto, L.; et al. Direct Pharmacological Targeting of a Mitochondrial Ion Channel Selectively Kills Tumor Cells In Vivo. Cancer Cell 2017, 31, 516-531. [CrossRef] [PubMed]

128. Szabo, I.; Zoratti, M.; Biasutto, L. Targeting mitochondrial ion channels for cancer therapy. Redox Biol. 2020, 42, 101846. [CrossRef]

129. Bachmann, M.; Rossa, A.; Antoniazzi, G.; Biasutto, L.; Carrer, A.; Campagnaro, M.; Leanza, L.; Gonczi, M.; Csernoch, L.; Paradisi, C.; et al. Synthesis and cellular effects of a mitochondria-targeted inhibitor of the two-pore potassium channel TASK-3. Pharmacol. Res. 2021, 164, 105326. [CrossRef]

130. Biasutto, L.; Mattarei, A.; La Spina, M.; Azzolini, M.; Parrasia, S.; Szabò, I.; Zoratti, M. Strategies to target bioactive molecules to subcellular compartments. Focus on natural compounds. Eur. J. Med. Chem. 2019, 181, 111557. [CrossRef]

131. Peixoto, P.M.; Ryu, S.Y.; Kinnally, K.W. Mitochondrial ion channels as therapeutic targets. FEBS Lett. 2010, 584, $2142-2152$. [CrossRef]

132. Heller, A.; Brockhoff, G.; Goepferich, A. Targeting drugs to mitochondria. Eur. J. Pharm. Biopharm. 2012, 82, 1-18. [CrossRef] [PubMed]

133. Ruan, L.; Zhou, M.; Chen, J.; Huang, H.; Zhang, J.; Sun, H.; Chai, Z.; Hu, Y. Thermoresponsive drug delivery to mitochondria in vivo. Chem. Commun. 2019, 55, 14645-14648. [CrossRef] [PubMed]

134. Hare, J.I.; Lammers, T.; Ashford, M.B.; Puri, S.; Storm, G.; Barry, S.T. Challenges and strategies in anti-cancer nanomedicine development: An industry perspective. Adv. Drug Deliv. Rev. 2017, 108, 25-38. [CrossRef] [PubMed] 